The results showed that the high lead children performed less well on all the tests including reaction time, word processing and standard IQ tests.

Professor Pat Lawther of St Bartholomews Medical School in London and chairman of a Department of Health and Social Security working party on lead pollution in the UK calls the Needleman study "the result of very careful work" but says that the statistics "have to be gone into in great detail" before he could evaluate it. "There are 39 variables subject to regression analysis, and besides, behavioural studies are very difficult" said Professor Lawther.

According to Anthony Tucker, science correspondent of The Guardian newspaper, the DHSS working party has been primarily concerned with criticising earlier studies that showed lead induced behavioural changes in children in the UK. "But since no studies of this standard or scale have been carried out in Britain or elsewhere it is difficult to see how its findings can be refuted" writes Tucker.

Meanwhile one of Britain's specialists on lead whose work is supported by Needleman's study, Professor Derek Bryce-Smith of the University of Reading, was subjected to some extremely unprofessional behaviour when he visited Stockholm recently to take part in a panel debate on lead and children. His visit followed a minor furore caused by the publication (in the journal Ambio) of an article which he coauthored, alleging that body lead levels considered normal in children actually appear to be pathogenic.

The article had prompted denials from two Swedish researchers, one of whom-Professor Åke Swenssonagreed to take part in the debate. In deference to Bryce-Smith, the Royal Academy of Sciences, which arranged the debate, announced that it should be held in English. This was duly printed on the programme and all the Swedes complied-except one. Docent CarlJohan Göthe, ignoring the chairman's admonition and in spite of the fact that there was no official interpretation provided, announced that he would speak Swedish. He then proceeded to attack Professor Bryce-Smith, coming to the very edge of personal insult. A little later he answered a question in English.

But Bryce-Smith himself was more disturbed by the behaviour of Professor Magnus Piscator, the other critic of the Ambio article. Piscator published his critique in a Swedish-language medical journal, accusing Bryce-Smith -among other things-of distorting information in some of his reference material. He made no attempt to contact Bryce-Smith to make his charges in English, and even refused to participate in the panel debate, saying it was stacked with people sharing BryceSmith's views-which was not the case.

"The allegation of distortion is untrue and libellous as far as we are concerned", says Bryce-Smith. "Piscator's articlc was extremely discourteous and unprofessional His behaviour is very irresponsible and not in the best traditions of science."

Professor Bryce-Smith was not impressed, either, with the level of the debate. "These people do not seem to be aware of recent literature on the subject", he said, citing the Needleman paper.

\title{
Soviet science boss refused Academy membership
}

Sergel P. Trapeznikov, the Soviet top Party hoss for science, has been refused full membership of the Soviet Academy of Sciences. So far as is known, this is the first time that the academy has ever refused an application from a member of the Central Committee of the Communist Party of the Soviet Union.

Trapeznikov is chairman of the Science Commission of the Supreme Soviet, and as such, formally has both the State Committee for Science and Technology and the Academy of Sciences under his jurisdiction. His appointment. however, was made on political grounds, not scientific. He has the reputation of a hardliner, and during the 1960 s vigorously opposed the economic reforms proposed by Professor E. G. Liberman, which were aimed at loosening the Party's hold over the economy.

Since his appointment as Chairman of the Science Commission in 1968, Trapeznikov has tried several times to get elected to the academy. In 1976, he finally achieved the rank of "Corresponding Member" (i.e. Associate Member). Election as Corresponding Member, however, does not require a vote from the full General Assembly of the Academy, but only confirmation by the general assembly of a decision already made by the relevant section.

Applications for full membership, however, must be discussed by the general assembly, and are then decided by secret ballot-the academy is the last remaining body in the Soviet Union to exercise this method of voting. It is due to this right of secret ballot that Academician Andrei D. Sakharov remains a member of the academy, in spite of several attempts to have him ejected.

Sakharov, indeed, took part in the debate on Trapeznikov's candidacy, stating that the latter's works on the collectivisation of agriculture were not of sufficient scientific value to qualify him for admission. Trapeznikov was rejected by a majority of 212 to 137 .

Regarding these figures, it is interesting that Mark Popovskii. a journalist who emigrated from the Soviet Union in 1977 claimed in his book Controlled Science, that secret ballot notwithstanding, there are certain members of the academy who would never dare vote against the election of the chairman of the Science Commission. Discussing just such an election as an example of the degree of "humility" the academy shows towards the Party, Popovskii states that the Chairman of the Science Commission (i.e. Trapeznikov) has within his competence the appointment of the directors of scientific institutes, "one of the most longed-for johs in the country". Secret ballot notwithstanding. Popovskii suggests that in such an election. although the "rank and file" academicians can "play their game of democracy", those who hold the post of director of an institute simply would not dare.

Popovskii also relates a number of other cases when persons of political status but insufficient scientific quality have been turned down by the academy. These include the present Minister of Education, V. P. Elyutin, and the Minister of Health B. V. Petrovskii. (The latter has in fact good medical qualifications, but medical personnel, however distinguished are not admitted to the Academy of Sciences... they must apply to the less prestigious Academy of Medical Sciences).

Some years back, however, the Academy of Sciences seems to have been more complaisant--during his term as Minister of Geology, Alaksandr V. Fedorenko managed to become a Corresponding Member (1953) and then a full Member (1966).

Why though should Trapeznikov and other politicians whose work verges on science be so keen for election to the academy? Is it simply a desire for increased status? Possibly. However, membership of the academy brings more than status; it includes a generous salary, and a number of valuable fringe benefits in housing and the like. Moreover, these are held, effectively, for life. Expulsion from the academy is virtually impossible, although it is reported that during the last few months the academy's statutes have been amended to ensure that anyone deprived of his Soviet citizenship would be automatically cxpelled.

Vera Rich 